\title{
健康家鬼血清の示す非特異性補體結合 反應物質（特に牛肺投補體結合反應に 於て）並其の一新除去方法に就て
}

\author{
故島田二郎
}

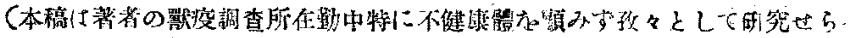

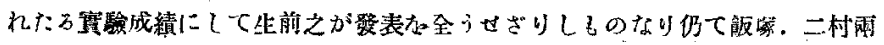

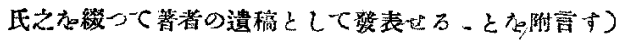

I. 緒 言

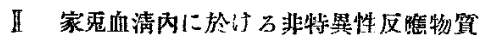
D所在

1 筑驗方法

2. 賽踰成績

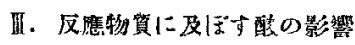

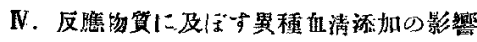

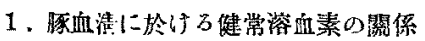

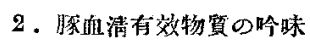

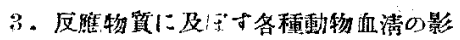
䌉

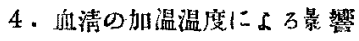

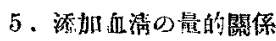

Y. 結諭

附引用琶目

\section{I. 緒}

흘

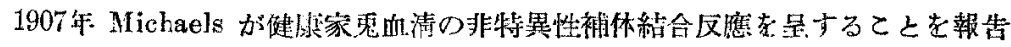

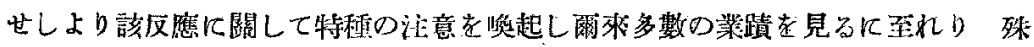
に Kolmer \& Tr'st は該反應に就て詳組なる研究の絬果單にリポオド性アンチダ

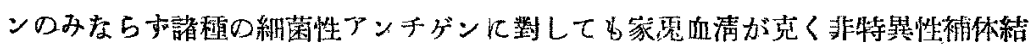
合反隼を是すべをてとを證明せり。

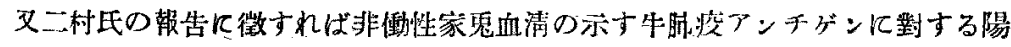
性反應率は $90 \%$ なと。

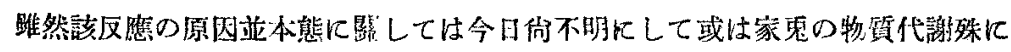
リポイド代謝に起因するるのならん之說くものありと踓何等望驗的根據を有せ

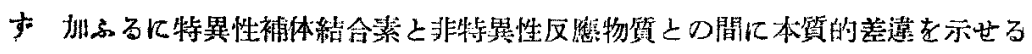
筫驗は甚た稀有に第す。 


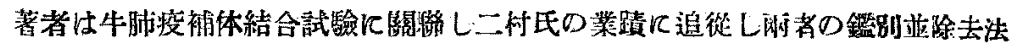

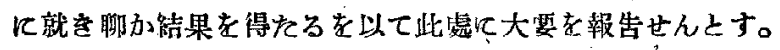

\section{II. 家患血清內に於ける非特異性反應物貢の所在}

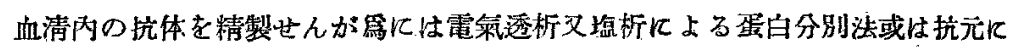

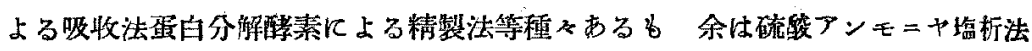
老用ひ可发的に各種血清蛋白を精製し之等に就て被体絬合反應を行ひ芜鬼血清に

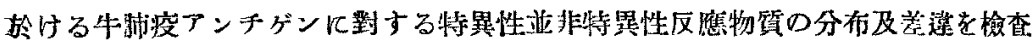
せんとせり。

然れども既に Ruppel の報告せる如く水に不溶性のオイグロビュリンもシウド グロビユリン溶液中に於ては稍く水に溶解するのみならす各種蛋白は種ふの感作

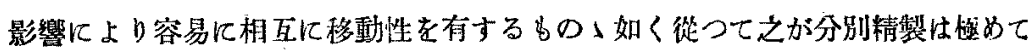
困難なる为のとす。

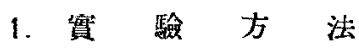

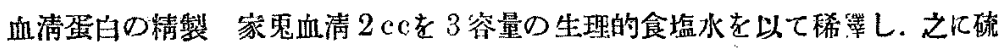
酸アンモニ十飽和液を $33 \%$ 割合に加へて生ぜし沈溉を遠心分離に依り集めて水

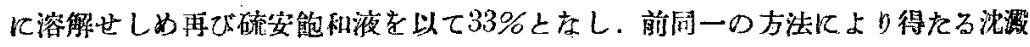
水溶液をコロヂウム囊に入れ流水中にて一書夜透析し．更に $10 \%$ 食塩水を以て等

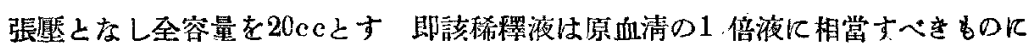
して之をオイグロビュリン フラクションとす。

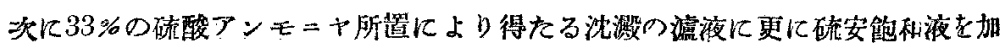

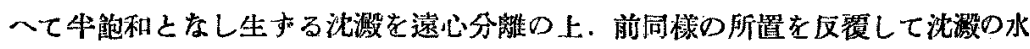

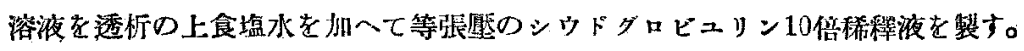

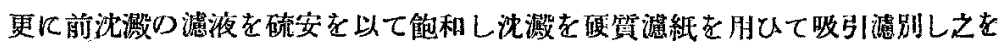

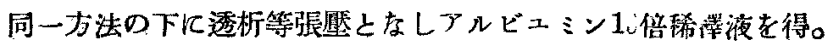

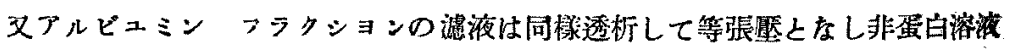
となす。

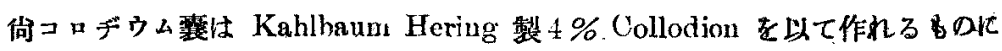
して一書夜の透析により硫酸アンモニヤは殆んど排除せられアンモニ+篦素の含 量は $8 \mathrm{mg} \%$ 以下となる。 
第 1 表

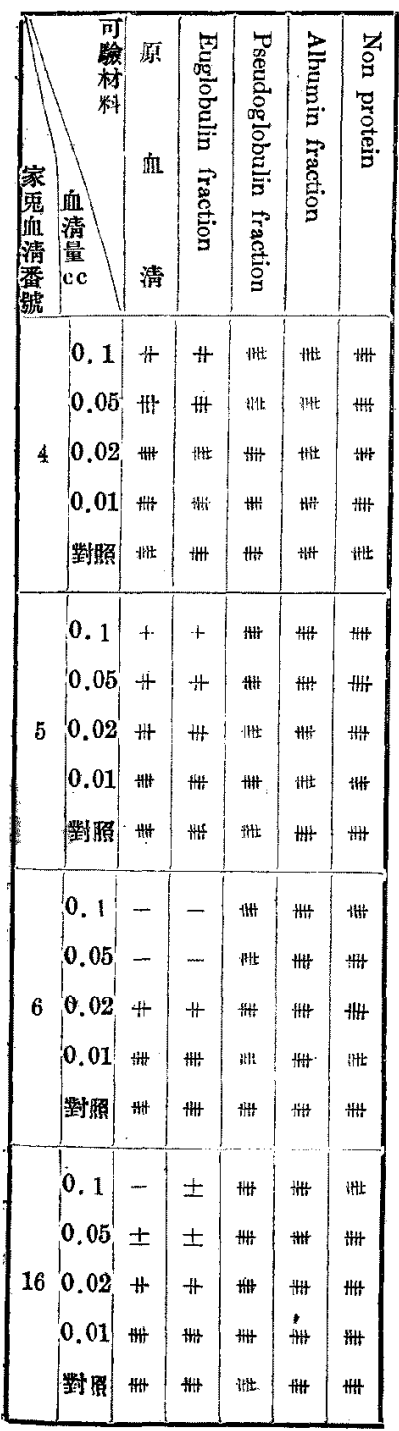

以上の各程再白稀釋液を攝氏56度に30分間 扠溫L非働性の上. 牛肺疫補体紹合反應老行 حb。

琎式 牛肺疫アンチゲンは獸发調查所製を 用ひ溶血系は緬羊血球系。梀体はモルモり下 血清を使用せり。

\section{2. 實 驗 成 績}

硫安所置により得をる各種稀譯液に就ての 試驗成續よりして健康家鬼血清の示す非特異 性補体結合反應物質屾常にオイグロビユリ ンフラクンョンに存在し該フラクションの 示す反應程度は無所琶原非働性血清のるのに 一政し何等反應の增減を認め難く，同時に才 イグロビェリン精製所琶に基〈抗補体作用の 出現等をし、反之シウドグロピユリン アル ビュミン及非蛋白部分は裐体結合反鷹に祭し 矮回完全溶血を示せし b之等稀釋液自体の溶 血作用家認めす。

其の成續は次表の如し。

又牛腈疫病毒を以てせる家鬼免狻血清內の

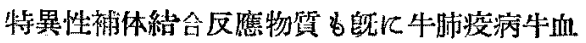

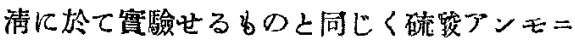
ヤを $33 \%$ 割合に加へて得たる沈澱部に完至 飞集め得らるっことを知兒せり 即ち次表の 如し。 


\begin{tabular}{|c|c|c|c|c|c|c|}
\hline 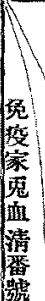 & $\begin{array}{l}\text { 血 } \\
\text { 清 } \\
\text { 量 } \\
\text { cc }\end{array}$ & 原 & 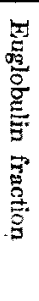 & 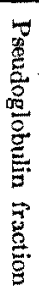 & 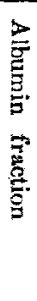 & 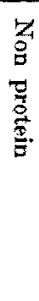 \\
\hline \multirow{8}{*}{3} & 0. & - & ' & & & \\
\hline & 0.05 & - & $\ldots$ & H⿻ & $x+4$ & 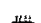 \\
\hline & 0.02 & $\ldots$ & $\rightarrow$ & th & tif & $\frac{1 \text {, }}{\text { thit }}$ \\
\hline & 0.01 & + & + & ant & 料 & thit \\
\hline & 0.005 & 4 & 卉 & 静 & 粇 & 推菲 \\
\hline & 0.002 & 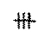 & $H$ & 龋 & $\frac{y+2}{x+3}$ & 夦 \\
\hline & 0.001 & his & 䖯 & 䢁 & 粹 & 楼 \\
\hline & 整基 & 䊔 & 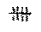 & 排 & 4 & 艚 \\
\hline \multirow{8}{*}{4} & 0.1 & - & - & \#t & 锥 & 喵 \\
\hline & 0.05 & \pm & \pm & tht & this & 地 \\
\hline & 0.02 & + & + & 碀 & 橉 & 䜤 \\
\hline & 0.01 & 4 & $\#$ & 猢: & Hit & +4 \\
\hline & 0.005 & 胡 & 严 & $H$ & 为 & 卌 \\
\hline & 0.002 & 胡为 & 辣 & Het & HA & $\mathrm{HH}$ \\
\hline & 0.001 & 维 & 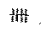 & 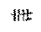 & 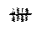 & 排 \\
\hline & 紧 & 洲 & 撒 & $H H$ & wts & 惟 \\
\hline \multirow{8}{*}{6} & 0.1 & - & - & 4 int & 计性 & 排 \\
\hline & 0.05 & - & $\rightarrow$ & tht & 诌位 & 䉽 \\
\hline & 0.02 & - & - & 料 & 㗅保 & Ittht \\
\hline & 0.01 & \pm & + & 科 & wht & 橉 \\
\hline & 0.005 & H & H & stiti & tht & sitt \\
\hline & $0.002^{3}$ & 臹 & 倣 & 册 & 诰 & 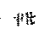 \\
\hline & 0.001 & HAt & 卌 & 紼 & sitt & ith \\
\hline & 齔 照 & Hith & 米 & Ha & 散 & 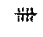 \\
\hline
\end{tabular}

而して淁蛋白各フラクションの空素を 定㖏するに磁酸アンテニ+33\%添汌によ

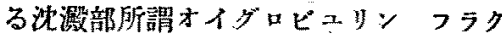
ションには水に不溶性のォイグロビュy ンと水可湓性の Howe のシウドグロピ ニリンI 含有するもの小如し，然れも゙

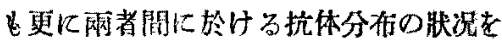
究むることは時に反鹪結果の一政を得奞 く容易ならざるか如し，而して各重抗体 のグロビェリン中に存在すべをは既に請 家の諰さ苟所在るむ更にオイグロビコリ ンとシウドグロビニリン閴に於ける分布

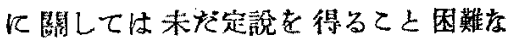
b。斯ち Ruppel は血清わ電策透析に よる蛋白口分則に於ては凝集素及補体緹 合素は主としてオイグロビュリン中に存 在しシウドグロビュリン中に證明せらる

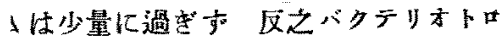
ビンの如を防㪘作用を有寸る物筑は大部 分媵者と斯存在すべをとと老報告世

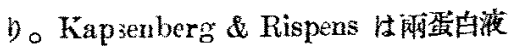
の等量を取り比校研究の絬果抗体の各> ラクションに於ける分有は雨者均等故り と。又 Laubeuheimer は電氣透析に上

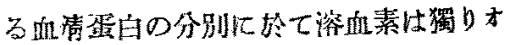
イグロビェリン中にのみ存在すへしと速

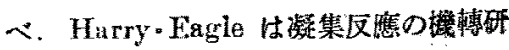
笔に關聯し抗体は常にグロビニリン中に 定量的に隨伴するる水不溶性オイグロビ 
シリン及可溶性シュドグロビュリン間に於げる分朴は區々にして不趛なることを 数告世口。

而して硫安 $33 \%$ 沈激部分を透析するに牛，豚等の血清に於ては水に不溶性部分 と可溶性部分之の分别は比较的容易なるも家鬼血清に於ては水汒不溶性部分少

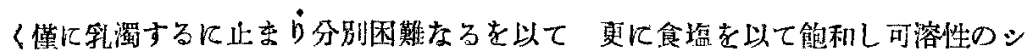
ウドグロビュリンとオイグロビュリンの沈澱とに分别の上网著の示才牛肺疫アン

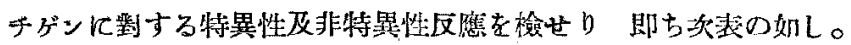

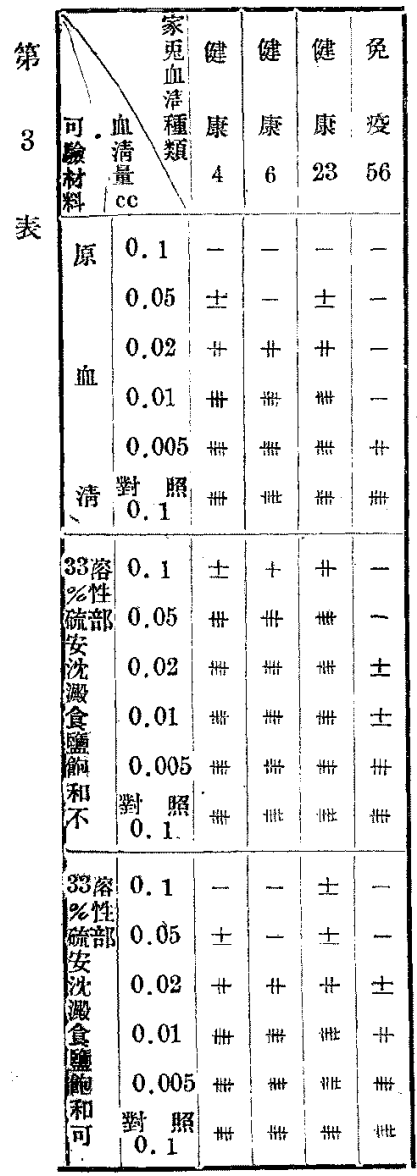

前坴の成䌭上りして家鬼血清の示与非特異

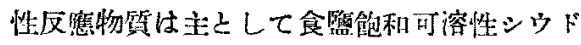
グロビコリン中に存在するを涩め反之特異性

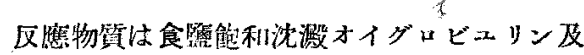
可溶性シウドダロビェリン何れにも登明せら るつが如をも他日の決定に待たんとす

\section{III. 反應物質に及ぼす酸の影響}

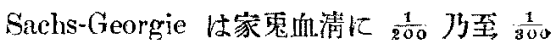

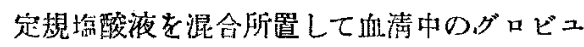
リンを沈降せしむることにより非特異性補休 絈命反應物質を除去し得ることを報告せり

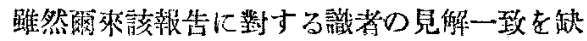
き直に肯定し能はざるか如し㷠に二村氏は

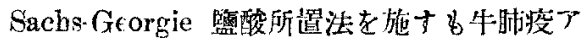
ンチゲンに對し傢需血清の示才非特異性補体

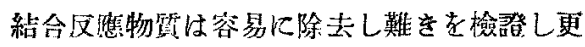

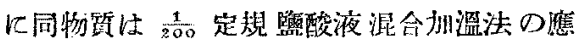
肘に位り完埾に除去D目的索逹し得ることを 愽明せり。

血清に留酸液を添加する時は血清は徐々に

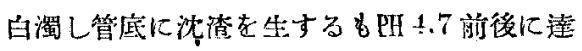

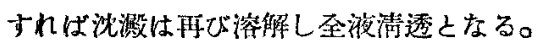




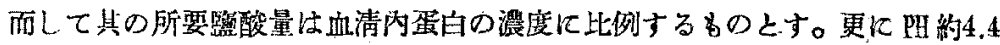

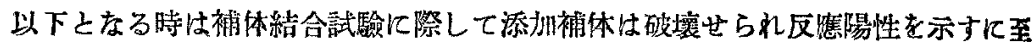

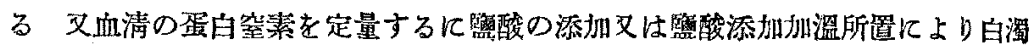

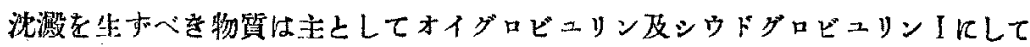

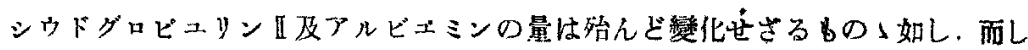

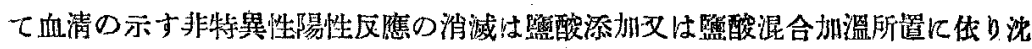

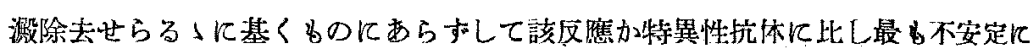

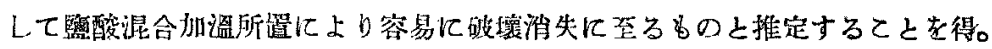

\section{IV. 反應物質に及ぼす異種血清添加の影響}

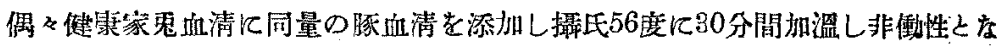

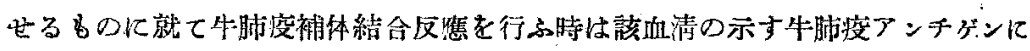

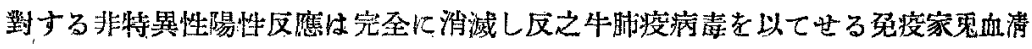

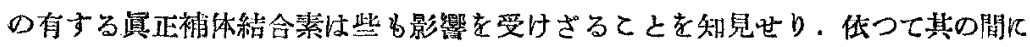
於ける消息を明にせんとし次記の曾驗老試みたり。

1. 眽血清に於ける健常溶血素の關係

豚血清に於て維羊血球儿對する健常溶血素を含むるのは最も多數なり從つて其 の影響を除去する目的を以て先つ緬洋血球を用ひて豚血清の健常豁血素を完全に

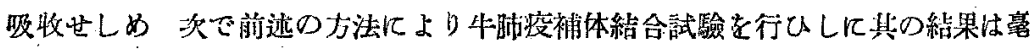

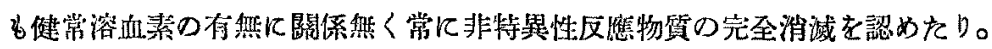

\section{2. 豚血清准效物質の坽䟱}

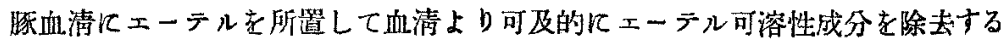
b該作用口減弱定認め難く。同時にェーテル可溶性フラクシヨンに於て方亦該作 用の證朋不能咕ることを實驗せり依つて更に血清を前述の硫酸安門分別法に基

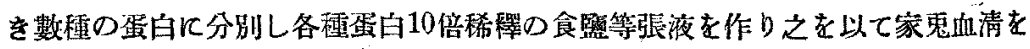

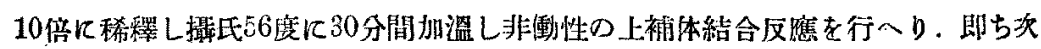
裁の如し。 


\begin{tabular}{|c|c|c|c|c|c|c|}
\hline 家鬼血清勫號 & 添加笓白種類 & \multicolumn{5}{|c|}{ 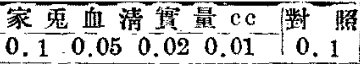 } \\
\hline \multirow{5}{*}{16} & L. & \pm & + & \# & HW & HW \\
\hline & 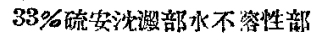 & th & He & 粆 & H & $\mathrm{H}+\mathrm{t}+\mathrm{H}$ \\
\hline & 33 '硫安沈测暗水可溶姓部 & + & $\pi$ & \# & 粠 & Hit \\
\hline & $33--50 \%$ 硫安泩激 部 & - & \pm & \# & 幽 & Hif \\
\hline & 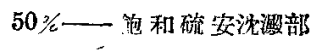 & & \pm & H & H & 耕 \\
\hline
\end{tabular}

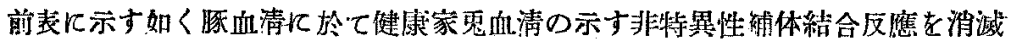
せしむべを作用を有する物質は䭂和液33\%の硫安沈澱部水不溶性部分に存在する

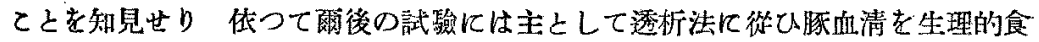

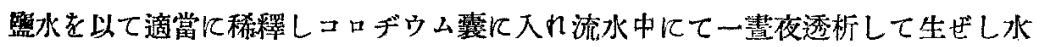

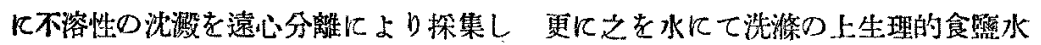

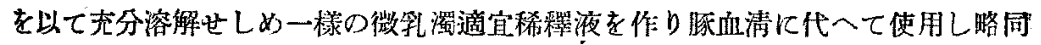
一反應線果を得てり。

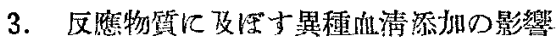

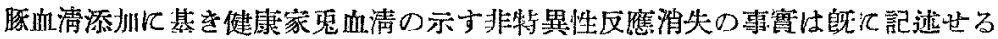
所なるも更に原以外の各䡚動物に由來する健应血清添加の場合に於ける反隹上の 影響を明にせんとし．全く牛肺㥄アンチゲンに對し陽性反憵を示ささる數種の嫦

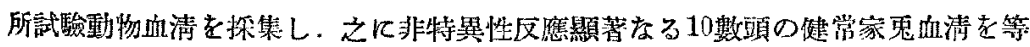

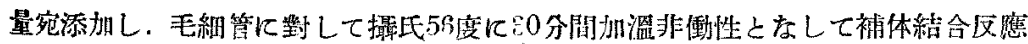
寺施行琼り。

10頙の健康豚及豚コレラ免捘豚より採集せる血清に就を核作朋の有然を檢

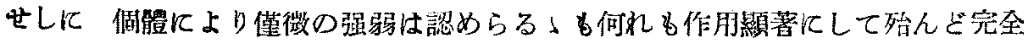

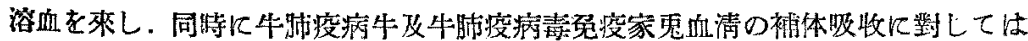
享に影響を示ささりき。即ち次表の如し。

\begin{tabular}{|c|c|c|c|c|c|c|c|}
\hline \multirow{2}{*}{$\begin{array}{l}\text { 家冤血清 } \\
\text { 番 號 }\end{array}$} & \multirow{2}{*}{$\begin{array}{l}\text { 添加睆血 } \\
\text { 清 番 號 }\end{array}$} & \multirow{2}{*}{ 壾 法 } & \multicolumn{4}{|c|}{ 家忽血清量量 c.c. } & 整照 \\
\hline & & & 0.1 & 0.05 & 0.02 & 0.01 & 0.1 c.c. \\
\hline 10 & - & 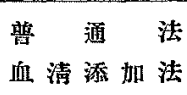 & + & H & $\begin{array}{l}\text { H } \\
\text { H }\end{array}$ & $\begin{array}{l}\text { H+lt } \\
\text { 耕 }\end{array}$ & 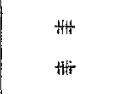 \\
\hline
\end{tabular}




\begin{tabular}{|c|c|c|c|c|c|c|c|}
\hline 11 & 2 & $\begin{array}{l}\text { 策 通 法 } \\
\text { 血清源加法 }\end{array}$ & \pm & $\begin{array}{l}+ \\
+4\end{array}$ & $\begin{array}{l}-11- \\
-13 \mid-1\end{array}$ & H & Hit \\
\hline 12 & - & 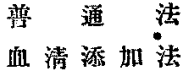 & int & $\begin{array}{l}\text { H } \\
\text { HH }\end{array}$ & thit & $\begin{array}{l}\text { 妌 } \\
\text { 州 }\end{array}$ & $\begin{array}{l}\text { 米 } \\
\text { 橉 }\end{array}$ \\
\hline 16 & - & 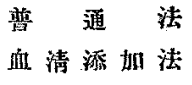 & - & $\begin{array}{l} \pm \\
\text { Hiti }\end{array}$ & H & HH & filt: \\
\hline 17 & - & $\begin{array}{l}\text { 搵 通 法 } \\
\text { 血清添加法 }\end{array}$ & \pm & + & $\begin{array}{l}\text { H } \\
H\end{array}$ & $\begin{array}{l}\text { H } \\
\text { H⿻丷木 }\end{array}$ & 瞔 \\
\hline 21 & - & 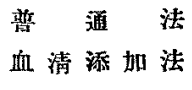 & $\begin{array}{l}H \\
H_{1}\end{array}$ & $\begin{array}{l}\text { H } \\
\text { Hin }\end{array}$ & H & 怆 & $\begin{array}{l}\text { 新 } \\
\text { 米 }\end{array}$ \\
\hline 22 & - & 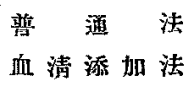 & $\begin{array}{l}4 \\
H \\
H\end{array}$ & $\begin{array}{l}\text { IIt } \\
\text { Hint }\end{array}$ & 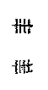 & ont & 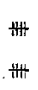 \\
\hline 23 & - & 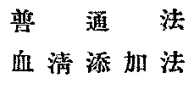 & - & - & $\begin{array}{l}H \\
H\end{array}$ & $\begin{array}{l}\text { H } \\
\text { 州 }\end{array}$ & 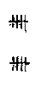 \\
\hline 24 & - & $\begin{array}{l}\text { 望 通 法 } \\
\text { 血满添加法 }\end{array}$ & $\begin{array}{l}+ \\
+n t\end{array}$ & 册 & int & $\begin{array}{l}\text { 掣 } \\
\text { Hill }\end{array}$ & 楼 \\
\hline 26 & 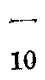 & 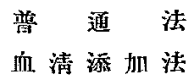 & + & $\begin{array}{l}H \\
+H\end{array}$ & 世 & 世 & 捧 \\
\hline
\end{tabular}

第 6 表

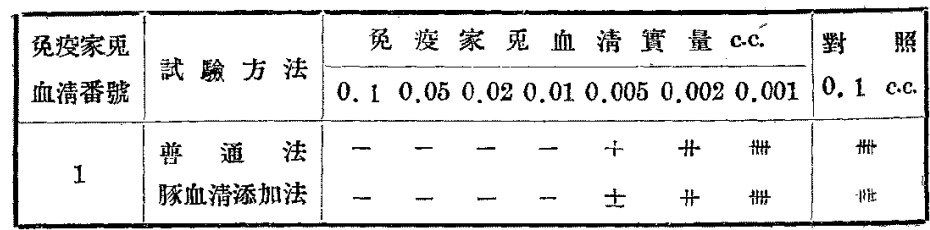

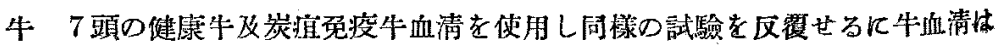

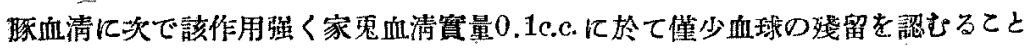
多し。唧ち次表の如し。 
第 7 表

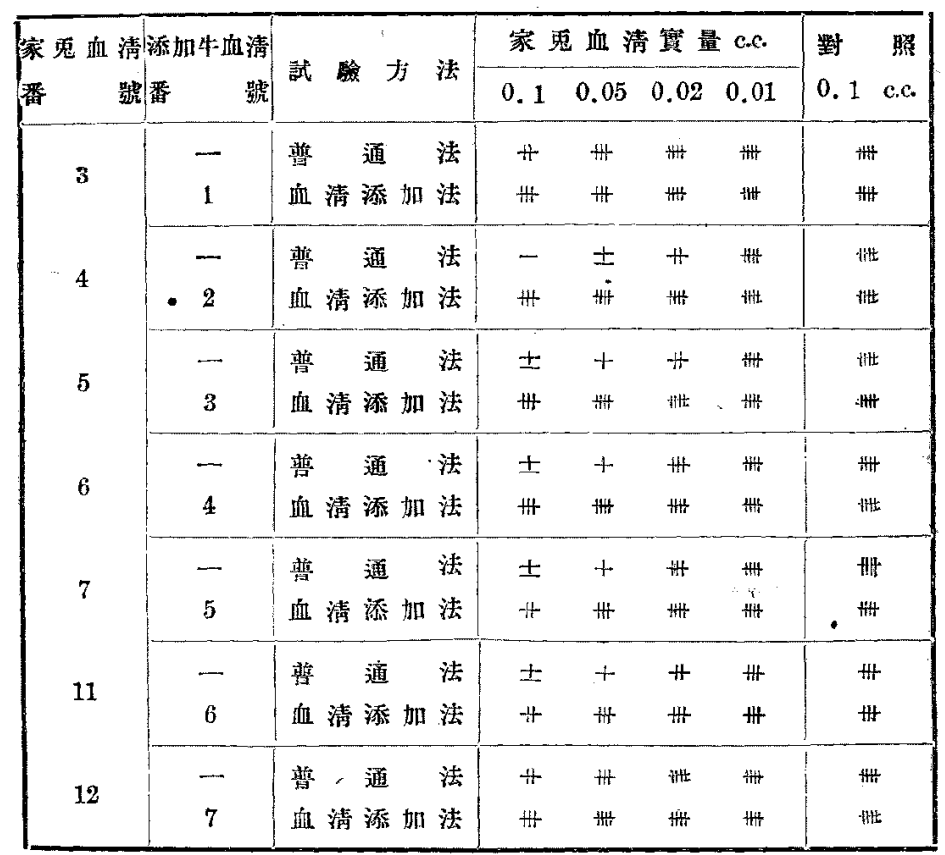

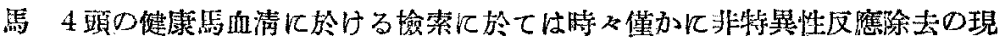
象を示すととあるb概して影響哭をるのとす。郎ち次表の如し。

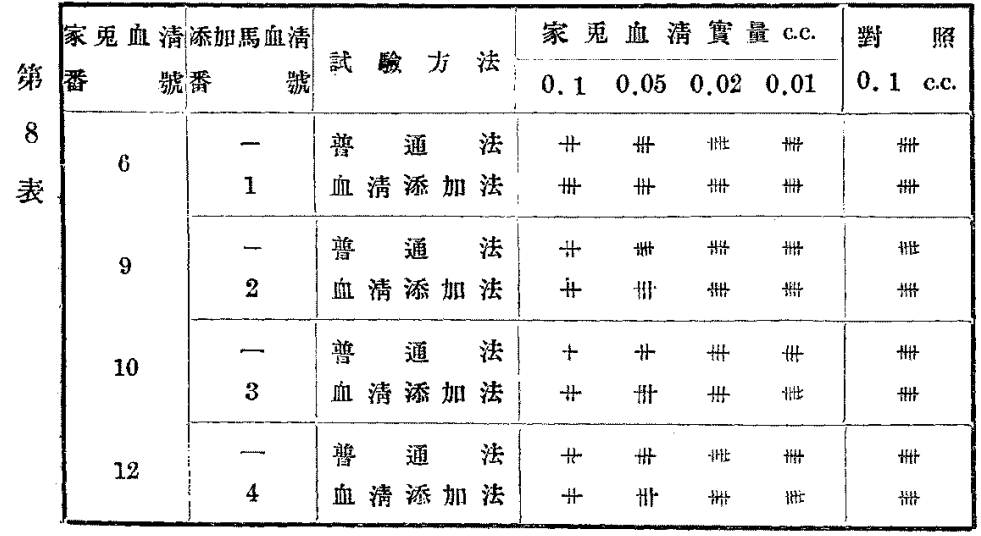


山羊及緬羊 健康山羊 2 頭刑健康緬羊 3 頭分血清に就ての检查成績に於ては何 れ非特異性物質除去の目的に對し何等效果的影響孝示さ才。郎ち次表の如し。

第 9 表

\begin{tabular}{|c|c|c|c|c|c|c|c|}
\hline \multirow{2}{*}{ 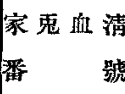 } & \multirow{2}{*}{ 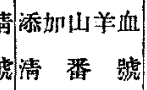 } & \multirow{2}{*}{ 試 殓 方 法 } & \multicolumn{4}{|c|}{ 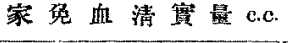 } & \multirow{2}{*}{$\begin{array}{l}\text { 龇 : 照 } \\
0.1 \text { c.c. }\end{array}$} \\
\hline & & & 0.1 & 0.05 & 0.02 & 0.01 & \\
\hline \multirow{2}{*}{11} & - & 瞕 道 法 & $\#$ & & titt & 制 & 桡 \\
\hline & 1 & 血清添加法 & + & H & 䩶 & 纯 & 㤡 \\
\hline \multirow{2}{*}{12} & $\cdots$ & 普 涌 法 & $H$ & & 册 & 米 & 册 \\
\hline & 2 & 血 清添加 法 & H & \# & 慛 & Hint & 曲 \\
\hline
\end{tabular}

第 10 表

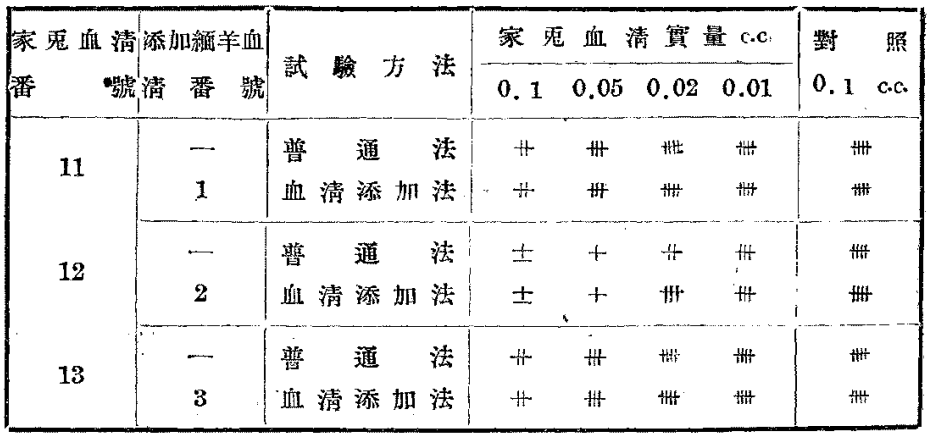

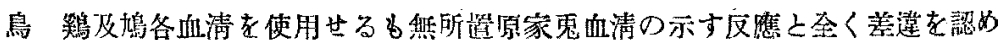
市。郎古次琵の如し。

\section{第 11 表}

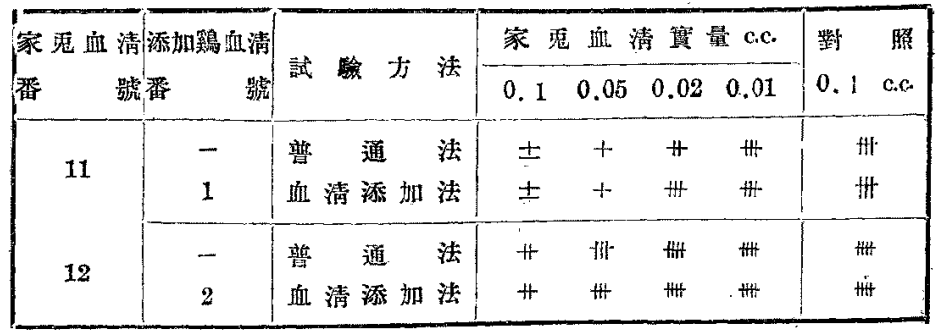




\begin{tabular}{|c|c|c|c|c|c|c|}
\hline \multicolumn{2}{|c|}{ 家息视清源加沜血清 } & \multirow{2}{*}{ 载 的方法 } & \multicolumn{3}{|c|}{ 家蒬，血、清锤量 c.c. } & \multirow{2}{*}{ 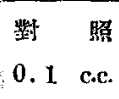 } \\
\hline 番 & 號番 號 & & 0.10 .05 & 0.02 & 0.01 & \\
\hline 11 & $\begin{array}{l}- \\
1\end{array}$ & $\begin{array}{l}\text { 蔫 通 法 } \\
\text { 血清添加 法 }\end{array}$ & $\begin{array}{l} \pm \quad+ \\
\pm .\end{array}$ & $\begin{array}{l}\# \\
H\end{array}$ & $\begin{array}{l}+1.5 \\
+4\end{array}$ & H \\
\hline 12 & $\frac{-}{2}$ & 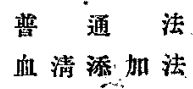 & $\begin{array}{l}H \text { H } \\
H \quad H\end{array}$ & thent & 眚 & 州 \\
\hline
\end{tabular}

モルモツト山羊縝羊及鳥類血菏の示す反應に同じく總て無影響なり。:

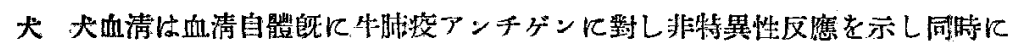

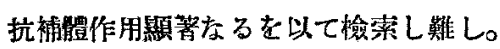

\section{4. 血清の加溫溫度による影響}

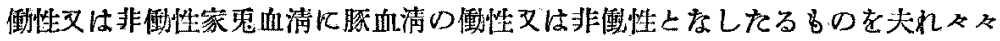

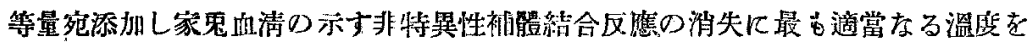

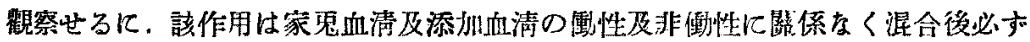

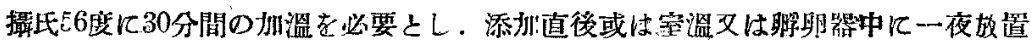
後血清の示す成績は反應に何等の變化壳認め難く常に多量の血球を殘有せり

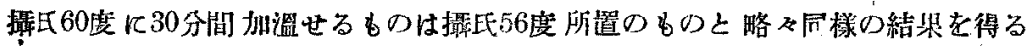

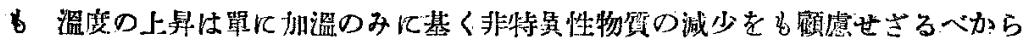

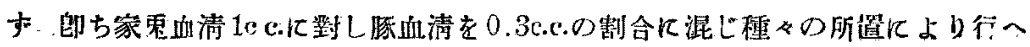
る咸續の 1 例至元せば次㳖の如L。

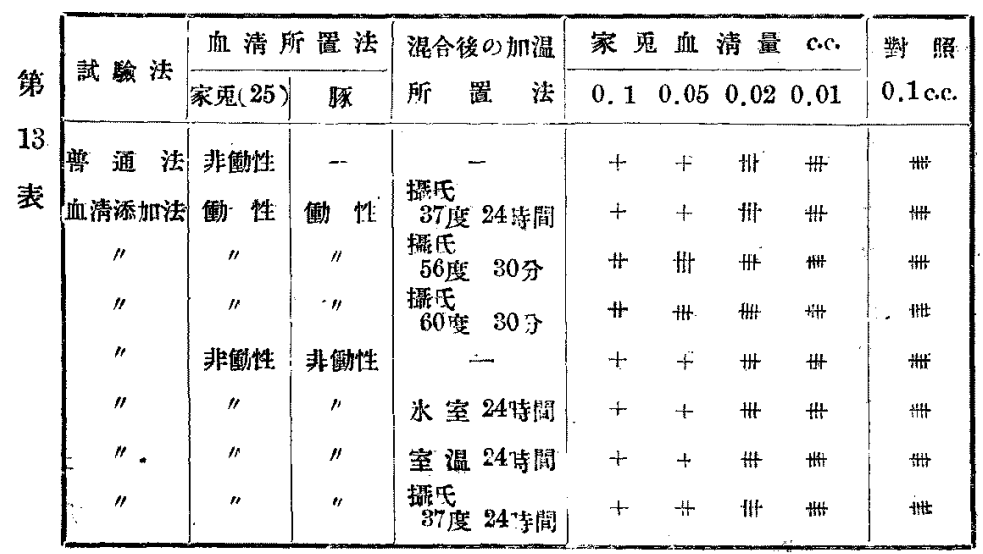




\section{5. 添加血清の量的關係}

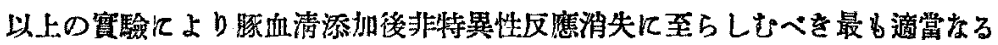

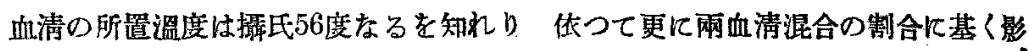

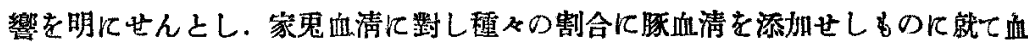
㵝及應を行へり 其の成績は次表の如し。

\begin{tabular}{|c|c|c|c|c|c|c|c|c|}
\hline \multirow{2}{*}{$\begin{array}{l}25 \text { 號家鬼 } \\
\text { 血清量 c.e. }\end{array}$} & \multirow{2}{*}{\multicolumn{2}{|c|}{$\begin{array}{l}\text { 添 加 跤 } \\
\text { 血清量 c.c. }\end{array}$}} & \multicolumn{4}{|c|}{ 家鬼血清實量 c.c. } & \multirow{2}{*}{$\begin{array}{l}0.1 \\
0.1\end{array}$} & \\
\hline & & & 0.1 & 0.05 & 0.02 & 0.01 & & \\
\hline 1.0 & & - & + & + & III & 耕 & & $t$ \\
\hline$"$ & & 0.1 & + & + & \# & witt & & * \\
\hline$"$ & & 0.3 & \# & $\#$ & $\#$ & & & $H$ \\
\hline$" \prime$ & & 0.5 & \# & 册 & 丼 & 册 & & H \\
\hline$"$ & & 0.8 & H & 曲 & H & H & & * \\
\hline$*$ & & 1.0 & 4 & 册 & 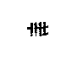 & 4 & & \# \\
\hline
\end{tabular}

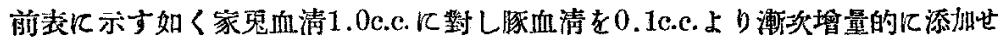

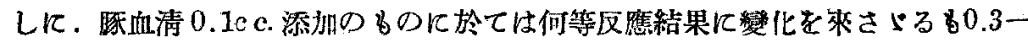

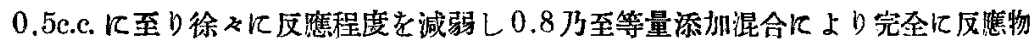
翼の消失を認めたり。

\section{V. 結 論}

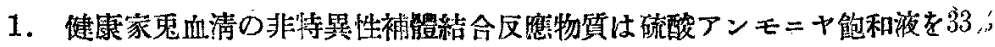
添加によりて生ぜしオイグロビニリン・フラ゙クション中に存在し主として水"溶 性シウドグロビュリン中に證明せらる。

2. 特異性補體結合素は主としてオイダロビュリン中に存在す。

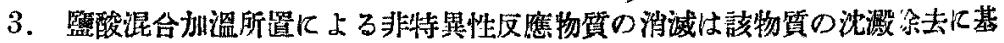
くものにあら該所固により破壤消失に至るbのの如し。

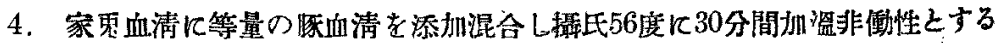

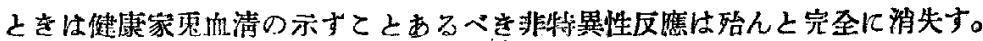


5. 鲧血清に於て家鬼血清の非特黑性反應を消失せしむべを物質は主として水 不溶性オイグロビユリン中に存在す。

6. 各種動物血清中非特異性反應除去作用の最も影著なるは原血清にして。次 て牛血清稍强く馬. 山羊. 緬羊及鳥の各血清は反應消失に殆んと影響を示さす。

7 暞血清添加に上り非特異性反應を消隇せしさるには該血清の等量添加を要 し同時に添加媵攝氏56度に30分閒の加溫を必要とす。

\section{附 引周書目}

1. Kalmer \& Trist; J. Inf. Dis. Vol. 18.20-64. 1916.

2. Ruppel, W. G. ;

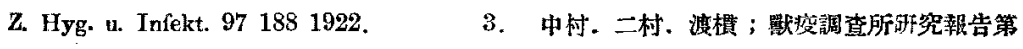
10 149面. 4. P. E. Howe; J. Bi . Chem. Vol. $491091922 . \quad 5$. Kapsenberg, G. \& Rispens, T. E. ; Z. Imm. 522271927.

6. Iasubenheimer, $\mathbf{K}$. \&. Vollmar, II. ; Z. IYyg. u. Infekt 1062021926. 7. Ifarry. Eagle; J. Imta. Vol. 181930. 8. Sachs-Georgie; Kl. W. N. 19. 8801923.

9. 二村.

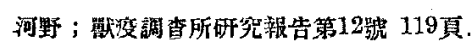

